
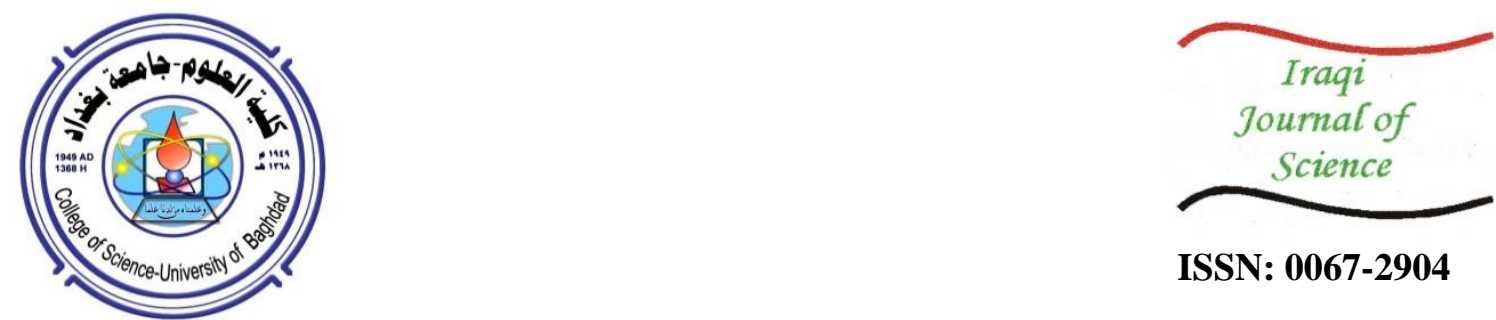

ISSN: 0067-2904

\title{
2D Seismic Reflection Study for Zubair Formation in East Nasiriya area, Southern Iraq
}

\author{
Mohammed S. Faisal*, Kamal K. Ali \\ Department of Geology, College of Science, University of Baghdad, Baghdad, Iraq
}

Received: 4/4/2021

Accepted: 26/5/2021

\begin{abstract}
An interpretive (structural and stratigraphic) study of the two -dimensional seismic data of East Nasiriya area $(30 \mathrm{~km}$ to the south east of Nasiriya oil field within Thi-Qar province, southeastern Iraq) was carried out using Petrel 2017 program. The study area has an importance due to its location between many oil fields, but still without exploration of oil wells. Twenty five seismic lines were used, date back to different types of seismic surveys conducted in the region at different time periods. Also, the seismic velocity surveys of the nearest wells to oil fields, such as Nasiriya-1 and Subba- 8 , in addition to their sonic and density logs were used. A synthetic seismogram with a good matching with the seismic section was achieved to ensure the identification of the reflectors and reflectivity type (peak or trough) and follow up each one through the whole area of interest. Top Zubair reflector was picked using the composite line to link the seismic sections with each other after enhancing the ties between seismic lines. Time and depth maps were made using velocity maps created from the velocity model. The seismic interpretation in the area showed the existence of certain stratigraphic features in the studied reflector. Some distribution mounds and sand lenses were observed in the study area, which are continuous in more than two-dimensional seismic line in the area. These activity elements provide a reasonable explanation for the distribution of hydrocarbons in the area of study.
\end{abstract}

Keywords: structural and stratigraphy, hydrocarbon indicators, Nasiriya oilfield, seismic reflection.

دراسة زلزالية انعكاسية ثنائية الابعاد لتكوين الزبير في منطقة شرق الناصرية- جنوبي العراق

$$
\begin{aligned}
& \text { تحمه سلمان فيصل * ، كمال كريم علي } \\
& \text { قسم علم الارض ، كلية العلوم، جامعة بغداد، بغداد، العراق } \\
& \text { أجلاصه دراسة تفسيرية للبيانات الزلزالية ثنائية الأبعاد لمنطقة شرق الناصرية (30 كم شرقا من حقل }
\end{aligned}
$$

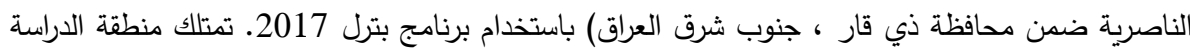

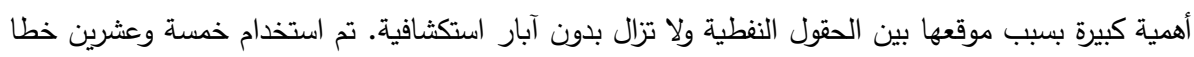

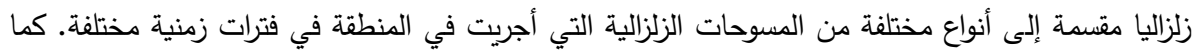

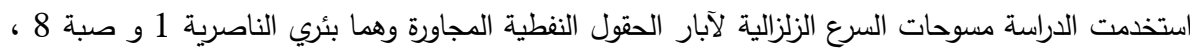

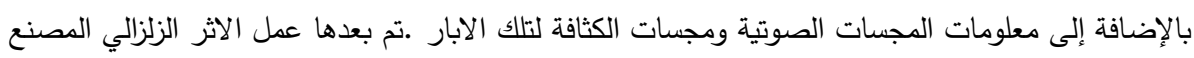




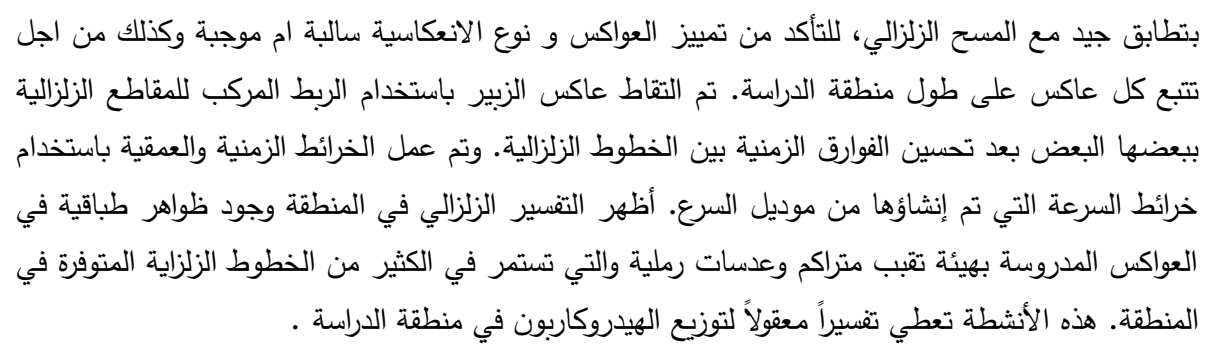

\section{Introduction}

The history of geophysical studies regarding hydrocarbon accumulations began in the last century when the seismic reflection method was used to detect the accumulations of hydrocarbons [1]. The seismic method can be considered as the most efficient geophysical technique in terms of cost and number of geophysicists engaged. The prevalence of the seismic method compared with other geophysical methods is attributed to several factors, such as the accuracy of results, high resolution, and high penetration of this method [2]. In petroleum exploration, the seismic method gives the accurate representation of the subsurface and geological structures of the earth. It provides a seismic section, along with velocity and time contour maps, to identify structural traps, provide stratigraphic interpretation, and recognize environmental depositions and sedimentary basin [3].

Numerous studies have been focusing on the Cretaceous succession in Iraq because it is the largest productive reservoir which contains about $80 \%$ of Iraq's oil reserves. One of the most important carbonate reservoirs in south east of Iraq is the Zubair Formation, which contains oil in structures of more nearest oilfields [4]. Zubair Formation was studied in Alakhadeir area and seismic attribute was used to distinguish some hydrocarbon indicators that refer to hydrocarbon accumulations [5]. Another work focused on studying Zubair, Yamama, and Najmah Formations in Kifl oil field by using seismic reflection data. Some structural and stratigraphic features were discussed [6]. Petrophysical properties (lithology, porosity, and water saturation) of Mishrif and Zubair Formations were estimated through the integration of well logs with seismic data [7]. A seismic reflection study of Wasit area aimed to investigate the four reflectors of Nahr Umr, Shuaiba, Zubair, and Ratawi Formations by using synthetic seismograms in the time domain of the wells in the area [8].

The current study aims to evaluate the structural and stratigraphic features of Zubair Formation in East Nasiriya area, using efficient software for the seismic interpretation of data of the Cretaceous period in the study area.

\section{Location and geology of study area}

The study area (about $2160 \mathrm{~km}^{2}$ ) is located in southern Iraq, including the Nasiriya city and extending to the east in Thi-Qar province. It lies within the Universal Transverse Mercator (WGS-84, U.T.M, Zone-38), having coordinates that are shown in table (1) and figure (1). According to previous studies $[9,10]$, the study area is located in the unstable pavement of the Mesopotamia region, with the flat topography covered by Holocene deposits within the Quaternary Period, which contains the flood plain deposits. The area is characterized by marshlands in most of its southern and eastern parts. Small rivers are present in the southern and north-western parts, in addition to the main Euphrates River which intercepts the area from the west and passes continuously to the south. 
Table 1- Coordinates of the study area.

\begin{tabular}{|c|c|c|}
\hline Corner Symbol & $\begin{array}{c}\text { E } \\
(\text { UTM })\end{array}$ & $\begin{array}{c}\text { N } \\
(\text { UTM })\end{array}$ \\
\hline A & 615332.55 & 3470323.16 \\
\hline B & 655971.87 & 3470323.16 \\
\hline C & 655971.87 & 3416346.61 \\
\hline D & 615332.55 & 3416346.61 \\
\hline
\end{tabular}

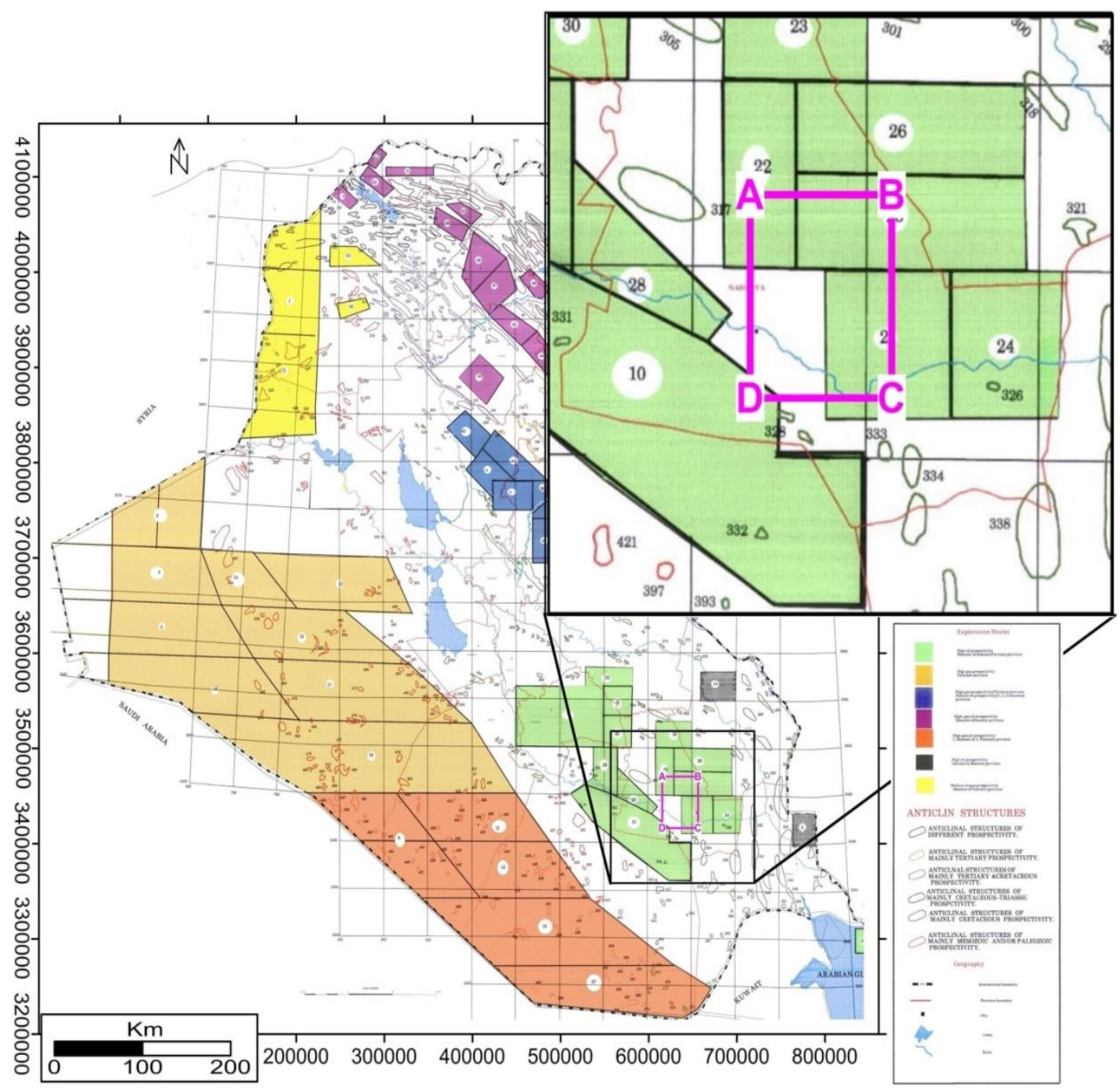

Figure 1- Location map of the study area [11]

The geological and geophysical studies which were prepared by the Oil Exploration Company (OEC) proposed that subsurface layers are inclined in the NE trend in the whole Nasiriya region [11]. The information of wells in the neighboring areas (Nasiriya and Subba oil fields) was also used during the current study. The target zone of the study, which is Zubair Formation, belongs to the Cretaceous age. The well Ns-1 was chosen to represent the stratigraphic column in the study area in southern Iraq (Figure 2). The total drilling depth of the geological column of well Ns-1 is about $3650 \mathrm{~m}$. The thickness of Zubair Formation is about $515 \mathrm{~m}$ [12]. 


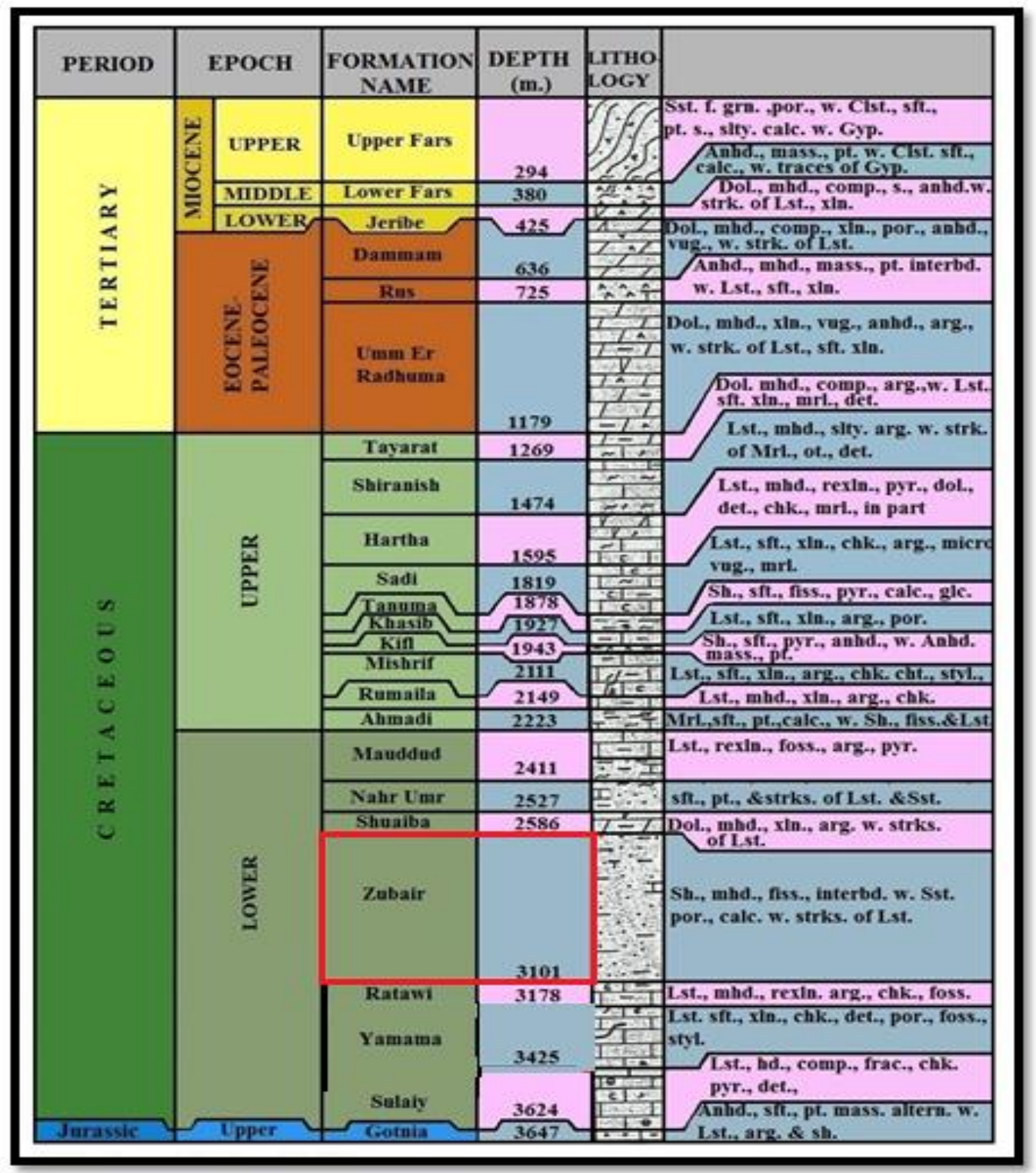

Figure 2- Geological stratigraphic column of Nasiriya well (Ns-1). The red rectangle encloses the studied formation [12].

\section{Zubair Formation}

The Zubair Formation, the most identified sandstone reservoir in Iraq, is consisting of fluvio- deltaic, deltaic, and marine sandstones. It covers large areas of the Arabian Plate, including northern Saudi Arabia, Kuwait, most of southern Iraq, and part of central Iraq. In Iraq, the formation was probably deposited in the Barremian. It is $200-500 \mathrm{~m}$ thick in southern Iraq [13].

The type locality is in the Zubair field and the Formation is divided into five units; these are (from the top): the Upper Shale (100 m thick), the Upper Sandstone, the Principal Reservoir, the Middle Shale, and the Lower Sandstone $[14,15]$.

\section{Data Base}

Three main types of data were used in the current study, which are:

1-Well Data: including well tops, total depths, Rotary Table Kelly Bushing (RTKB), sonic and density logs, and the coordinates of the wells beside the study area (Ns1 \& Su8 ). 
2- Well seismic data: including the check-shot for the wells Nasiriya 1 and Subba 8.

3- Seismic data: sets of two-dimensional seismic lines that cover almost all the study area; these are:

a- NN survey data, including NN23 which is the line passing through the well of Nasiriya-1.

b- N survey data, including nine lines, which are N14, N15, N17, N19, N21, N23, N25, N25, and N41.

c- $\mathrm{H}$ survey data, including eleven lines, which are (H4), (H5), (H6), (H7), (H9), (H110), (H11), (H12), (H13), (H14), and (H15)

d- HN survey data, including seven lines, which are (HN11), (HN23), (HN25), (HN27), (HN29), (HN155), and (HN177).

e- (SL) survey data, including five lines, which are (SL12), (SL14), (SL16), (SL18), and (SL19).

The data processing was carried out by the Oil Exploration Company. The number of seismic lines used in the present study is 25 , distributed along the study area and taken in different directions according to the design that was considered during the preplanning of survey.

\section{Base Map Preparation}

The processed seismic data is loaded to the interactive workstation of the OEC interpretation department in SEG-Y format. Some of the lines do not contain $\mathrm{x}$, y coordinates. Thus, we needed to use the "Data Toolbox", which is an extension in Petrel used to add coordinates and load seismic lines, and then construct a base map of the study area. Figure 3 shows a collection of 2D seismic lines; each survey has its own color.

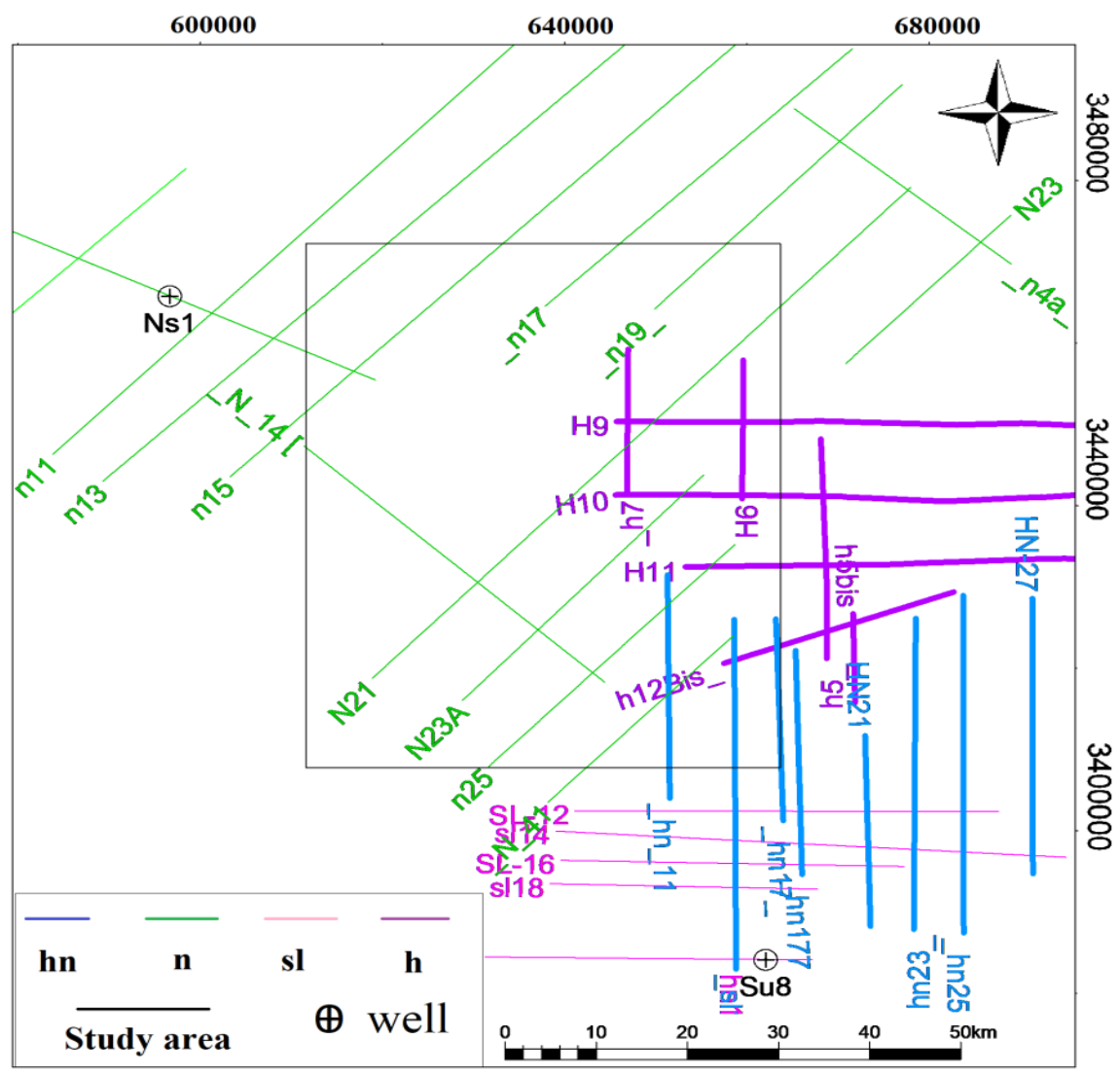

Figure 3- Base map of the study area.

\section{Creating the Synthetic Seismogram}

The process to create the synthetic seismogram consists of two steps. The first step is to perform sonic calibration through the calibration of sonic and velocity logs. The value of the 
calibrated sonic log curve was multiplied by that of the estimated density log curve to calculate the acoustic impedance, followed by the calculation of the reflection coefficient. The deterministic wavelet was convolved with the reflection coefficient to generate a synthetic seismogram section; this is the second step of the processing. The original seismic section showed a good match with the synthetic seismograms (Figure 4).

\section{Delineation of Seismic Reflectors}

The most important process in seismic interpretation task is the picking of horizons. The higher accuracy in picking horizons leads to higher accuracy of interpretation results. General analysis of the seismic sections that are shown in the software gives us an indication on the reflector to be studied, its continuity over all the area, and the matching between the same reflectors at the intersection points, in addition to the quality of the reflector (Figure 5).

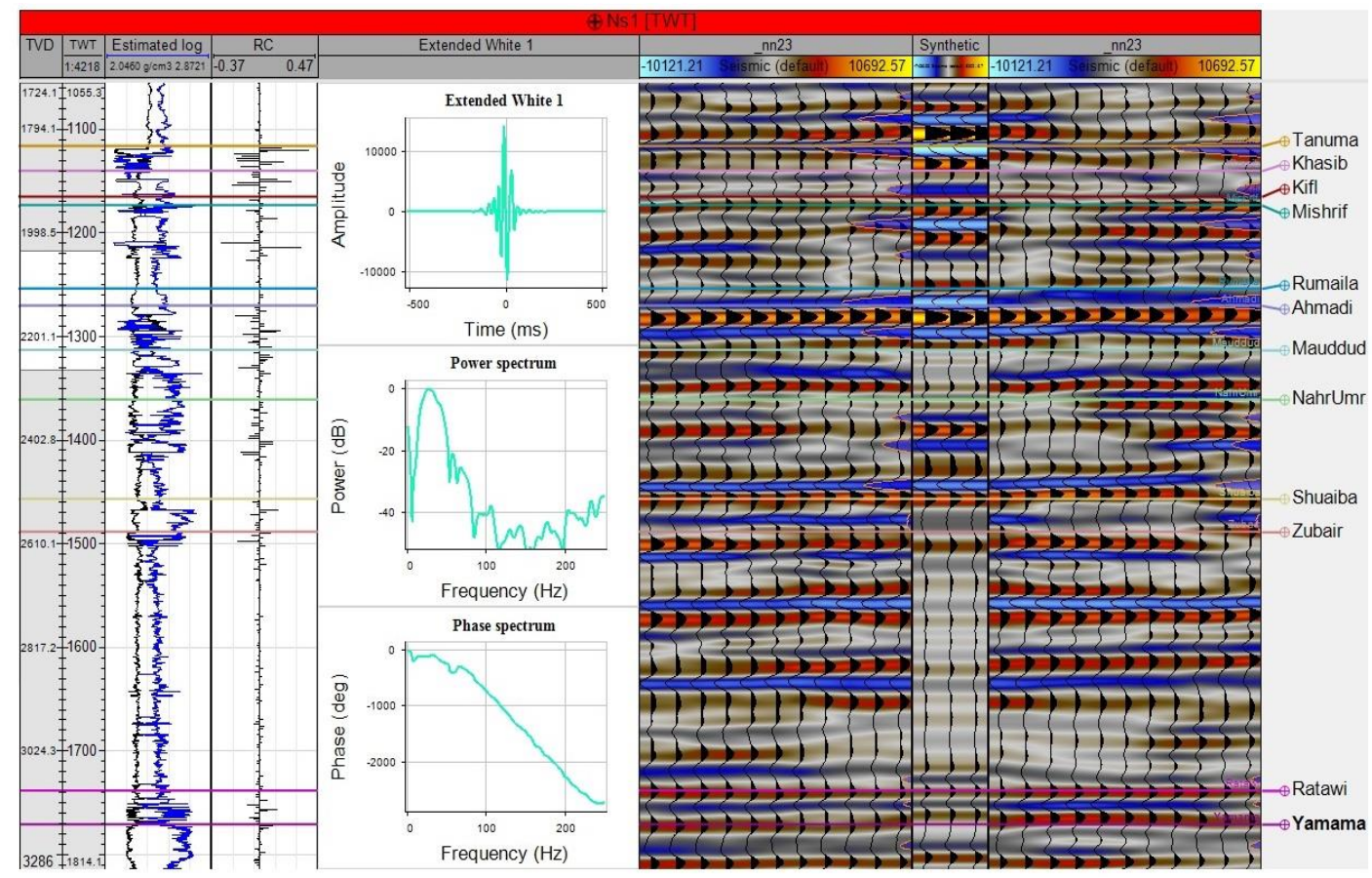

Figure 4-Synthetic seismogram of well Ns-1 and its required parameters.

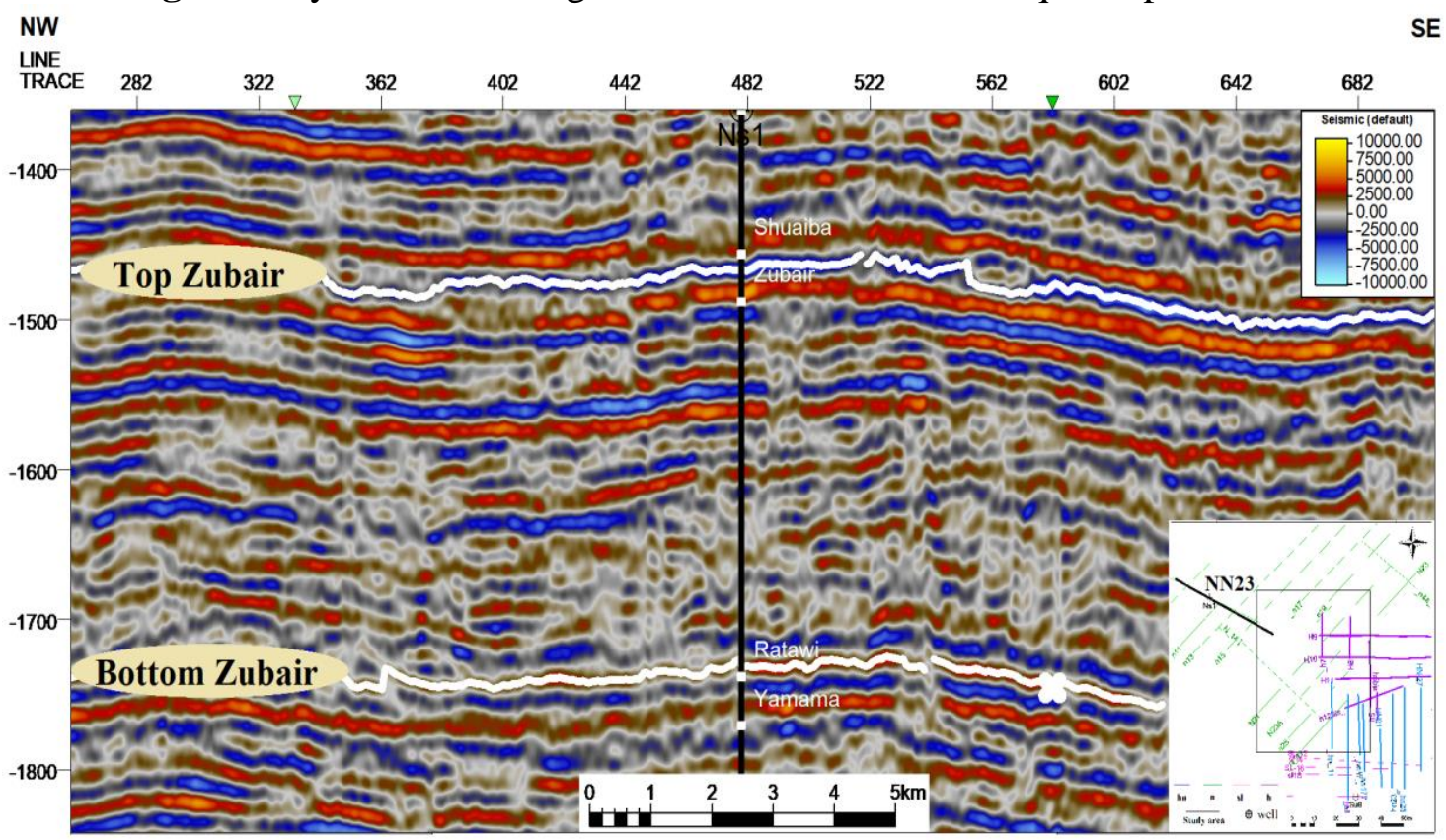

Figure 5-The seismic section passing through the well Ns-1. 


\section{Two-Way Time (TWT) Map}

Because the area is considered as an extension of the neighboring oil fields, it was interpreted based on its seismic lines in addition to some adjacent lines in order to give a complete structural picture of the region. The picked horizons of top Zubair Formation were used to construct the two-way time maps using Petrel software. The map in Figure 6 represents two-way time between sea level and the top of Zubair reflector, which is picked as a trough as a result of negative reflectivity between the limestone and sandstone. It appears that the lowest value of TWT is at the west $(1000 \mathrm{~ms})$, while the highest value is at the northeast $(2250 \mathrm{~ms})$. The effect of transverse fault system in the region is clearly observed, located at the north-east in Zubair TWT map, which is correspondent to the transversal blocks map shown an earlier study[16].The Takhadid-Qurna Fault Zone, as one of the transversal fault system divisions in Iraq, comprises a series of faults defined by gravity gradient measurements. It forms the $\mathrm{N}$ boundary of the Zubair Subzone. This block subsided during the Late Cretaceous and Palaeogene. N-S trending structures are predominant in the Stable Shelf. In the Mesopotamian Zone, they comprise prominent long buried anticlines and faults [16].

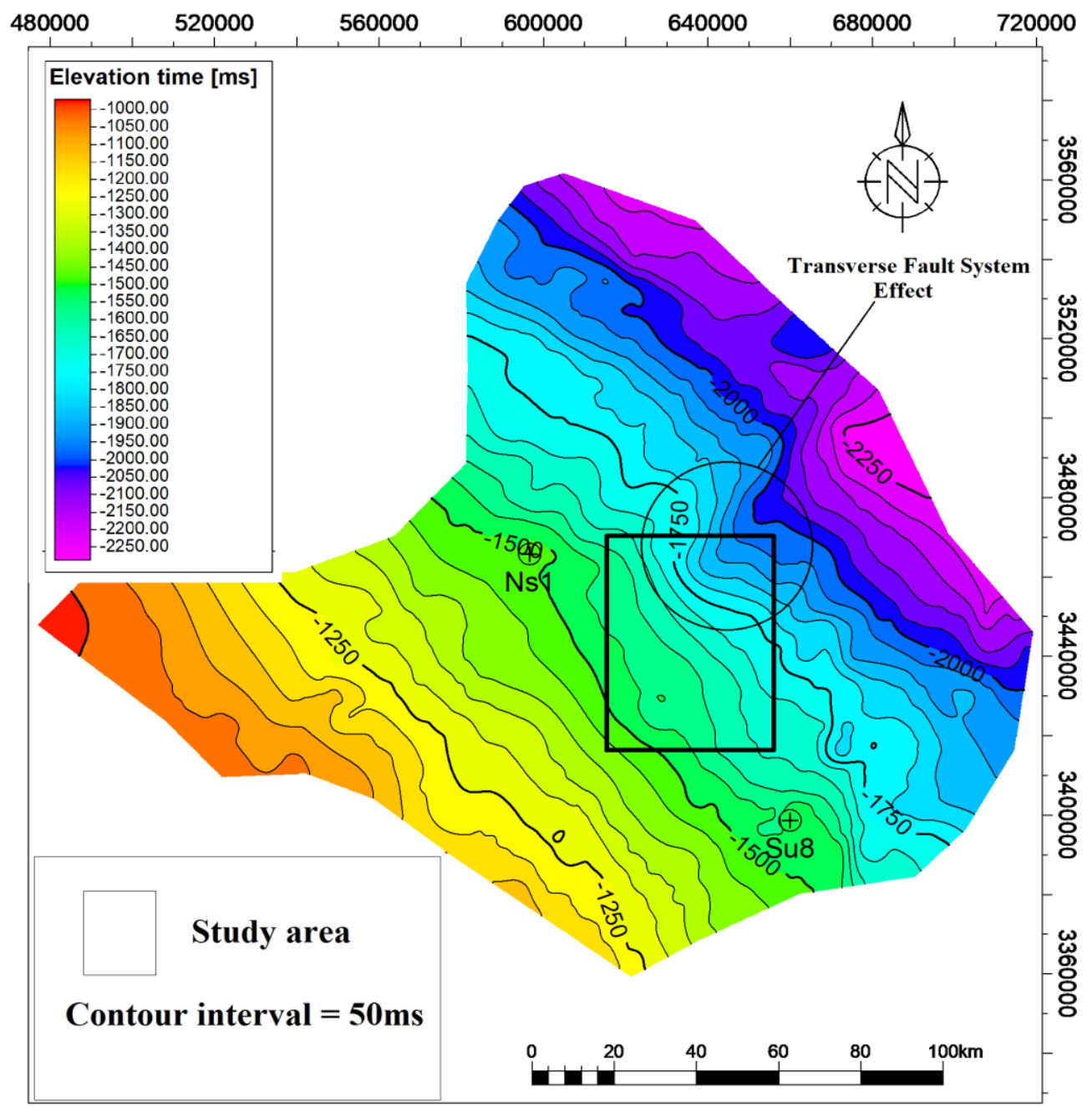

Figure 6-TWT map of top Zubair Formation.

\section{Depth Maps}

There are many ways to convert time maps into depth maps, and one of the most important of these methods is the velocity model method, which was used in this study to construct depth maps from sea level datum to the top of Zubair Formation. Figure 7 shows that the 
general depth trend is NW- SE direction for the top of Zubair Formation. The minimum depth value $(1900 \mathrm{~m})$ was noticed at the west and gradually increased toward the east and north east to reach $3900 \mathrm{~m}$. By matching the depth values of the studied formation with locations of hydrocarbon indicators in seismic lines, the middle and eastern parts of the study area can be considered as promising areas for hydrocarbon exploration.

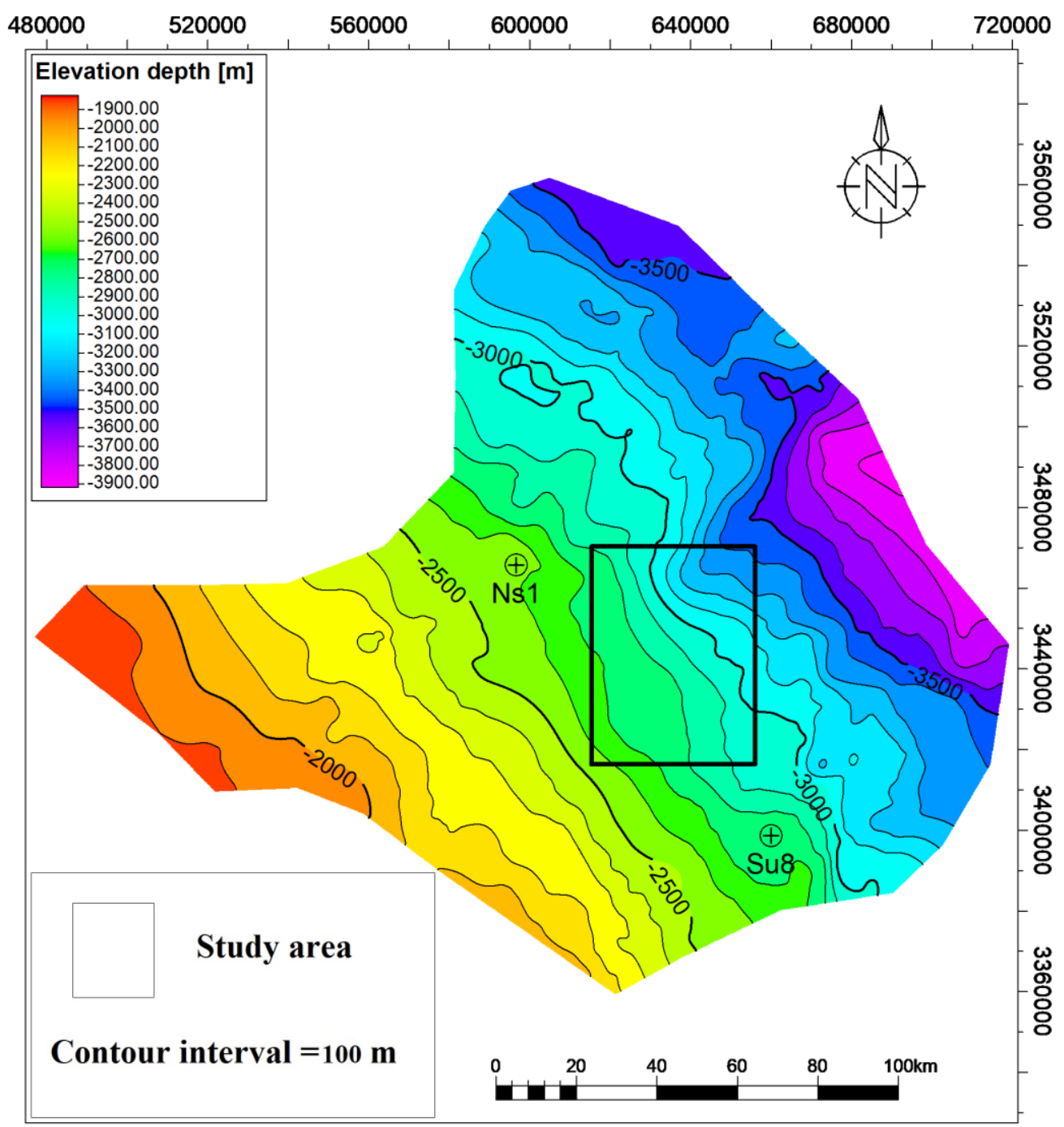

Figure 7-Top Zubair depth map.

\section{Direct Hydrocarbon Indicators}

Geophysical studies proved that the presence of hydrocarbon matters in the pores of a sedimentary layers leads to lowering both the seismic velocity and bulk density of these layers [8]. Mound and sand lense indicators were detected in seismic sections within the study area, which are shown in Figures 8 and 9. These indicators appear in the seismic lines to the east of the study area within Zubair Formation, which is considered as one of the main reservoirs in the neighbored oilfields. The study area is surrounded by the west Qurnah, Saba, Deima and Nasiriya oil fields from the directions of east, south, north-east and north-west, respectively. In all these oilfields, Zubair Formation is considered as one of the important reservoirs. 


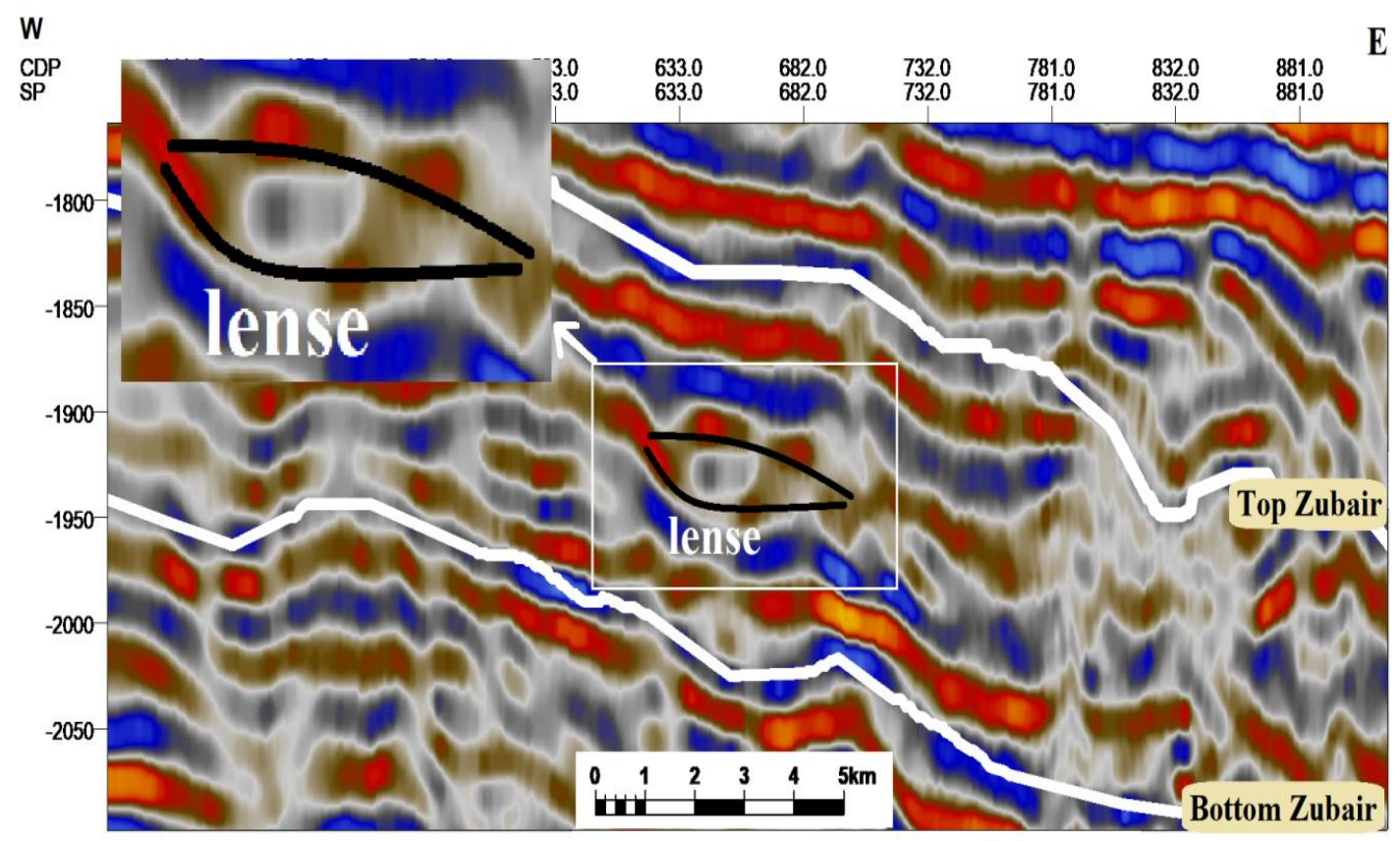

Figure 8-Sand lense in seismic section H5.

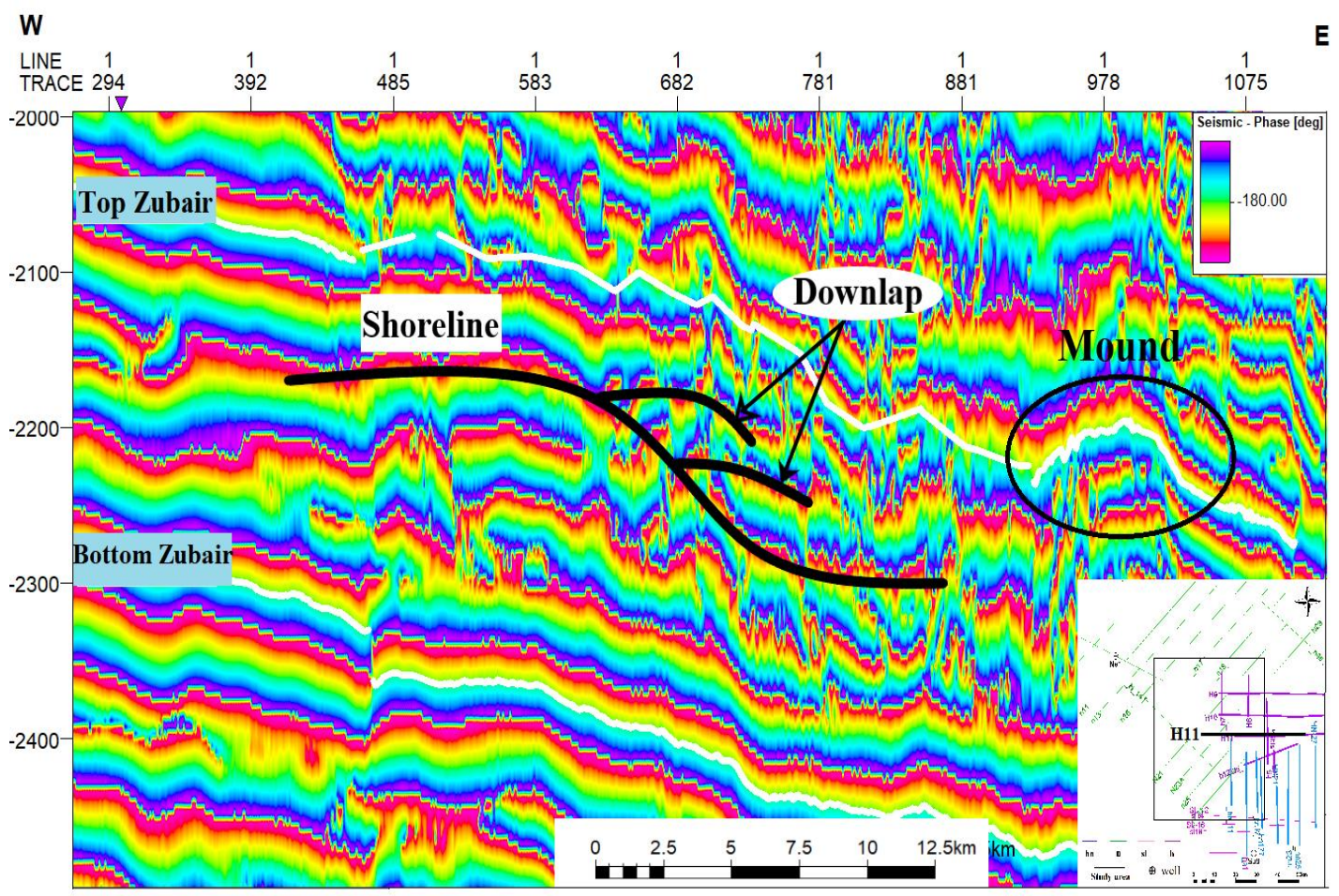

Figure 9-Mound and downlap configuration in seismic section H11.

\section{Conclusions}

The TWT map of Zubair reflector showed the existence of transverse fault system effect in the North-East direction as a big nose structure and also the time values increase to the North East $(2250 \mathrm{~ms})$ with decreasing to the west $(1000 \mathrm{~ms})$. The slope trending of the study area is NE-SW, which is prepared to contain a hydrocarbon accumulation. The depth map of the top Zubair reflector showed that the depth increases to the North East $(3900 \mathrm{~m})$ and decreases towards the west of the study area $(1900 \mathrm{~m})$. Mound and sand lenses were observed 
in the seismic sections, which represent direct hydrocarbon indicators for the probable presence of hydrocarbon reservoir in the study area.

\section{References}

[1] Berg, O., "Seismic Detection and Evaluation of Detta and Turbidite sequences: Their Application to exploration for The Subtle trap", AAPG, vol. 66, no. 9, pp. 1271-1288, 1982.

[2] Hart, Bruce S., Principle of 2D and 3D seismic interpretation, McGill University, 2004, 443p.

[3] Milsom, J., Field Geophysics, 3rd. Ed. University College London, 2003, 232 p.

[4] Khorshid S. Z. and Kadhm A.D. "Subsurface Investigation of Oligocene Geologic Formations Age, East Baghdad Oil Field". Iraqi Journal of Science, vol. 56, no. 4C. pp. 3441-3451, 2015.

[5] Ali, K., K., and Kadhim, F., G., "3D seismic attributes interpretation of Zubair Formation in AlAkhadeir area, south western Karbala", Iraqi Journal of Science, vol.56, no.4C, pp. 36133524, 2019.

[6] Fadhel. S., Seismic Reflection Study of Lower Cretateous Rocks in Kifl Oil Field, Iraq, thesis of master of science in Geophysics, Geology Department, Baghdad university, 2010, 142p.

[7] Hashim, H. A., Seismic Inversion as A tool for Reservoir Characterization at Zubair and Mishrif Formations in Al-Rafidain Oil Field - Southern Iraq. PHD. Thesis (Unpublished), Baghdad University. 2017, 156p.

[8] Al-Ridha N.A. and Ali H. M. "Study the Image of Wasit Subsurface Structure Using 3D Seismic Data Center of Iraq" . Iraqi Journal of Science. vol.56, no. 4C, pp.3513-3523, 2015.

[9] Jassim, S. Z., \& Goff, J. C. Geology of Iraq (1st ed.). Prague. Czech: Dolin, Prague and Moravian Museum, Brno, 2006, 470p.

[10] Sissakian, V. K. and Fouad, S. F. D. B. Geological Map of Iraq1:1,000,000 Scale Series, sheet No. 1, Publication of GEOSURV, Baghdad, 2012.

[11] Oil Exploration Company, Integrated study of Nasiriya oil field, (23/A/17), (in Arapic), 2011.

[12] Oil Exploration Company., Report of 2D seismic survey project for the block 11 . A /1/230, 2015.

[13] Aqrawi, A.A.M., Goff, J.C., Horbury, A.D., and Sadooni, F.N., The petroleum geology of Iraq published by scientific press Ltd, 2010, 27p.

[14] Aqrawi, A.A.M., Thehni, G.A., Sherwani, G.H. and Kareem, B.M.A., "Mid- Cretaceous rudistbearing carbonates of Mishrif Formation: An important reservoir sequence in the mesopotamian Basin", Iraq. Journ. Petrol., vol. 21, pp.57- 82, 1998.

[15] Al-Zaidy, H. Aiad, "Facies Analysis and Sequence Stratigraphy of the Zubair Formation in the Kifl oil field, Central of Iraq". Iraqi Journal of Science, vol. 60, pp. 341-352, 2019.

[16] Jassim, S. Z., \& Buday, T. Units of the Stable Shelf. In S. Z. Jassim, \& J. C. Goff (Eds.), Geology of Iraq. Czech Republic: Dolin, Prague and Moravian Museum, Brno., 2006, pp.73-90. 